\title{
EFFECT OF PHOSPHORIC ACID AND POTASSIUM HUMATE ON GROWTH AND YIELD OF MAIZE IN SALINE-SODIC SOIL
}

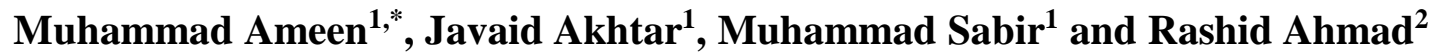 \\ ${ }^{1}$ Institute of Soil and Environmental Sciences, University of Agriculture Faisalabad-38000, Pakistan; ${ }^{2}$ Department of \\ Agronomy, University of Agriculture Faisalabad-38000, Pakistan. \\ "Corresponding author's e-mail: soilchemist.ameen033@gmail.com
}

\begin{abstract}
Phosphorus (P) is the $2^{\text {nd }}$ most deficient nutrient among plants $\left(<10 \mathrm{mg} \mathrm{P} \mathrm{kg}^{-1}\right.$ soil $)$ in $>90 \%$ soil of Pakistan. The crop requirement is achieved by fertilization however effectiveness of the current $\mathrm{P}$ (Phosphorus) containing fertilizers applied as broadcast is less (20\%). Application of phosphoric acid (PA) and potassium humate $(\mathrm{PH})$ not only increases the nutrients availability to plant but also improves soil characteristics. A pot experiment was carried out to evaluate the behavior of PA and $\mathrm{PH}$ in saline-sodic soil for nutrient availability in maize. Twenty-seven plastic pots were used in this experiment. PA was applied according to recommended dose of Punjab Agriculture Department (NPK 200-150-200 kg ha-1), while the PH was applied according to the Agrolix fertilizer private limited recommendation (50 and $100 \mathrm{~kg} \mathrm{ha}^{-1}$ ). The plant growth parameters (length and dry weight of root and shoot), ionic interaction (N, P, K, Fe, $\mathrm{Zn}, \mathrm{Cu}$ and $\mathrm{Mn}$ in root, shoot and grain) and grain weight were recorded. The results showed $241 \%$ and $315 \%$ more shoot and root dry weight as compared to control with combined application of PA and PH. The length of shoot and root were improved to $181 \%$ and $232 \%$ as compared to control. The grain yield was positively correlated with shoot dry weight $\left(\mathrm{r}^{2}=0.6618\right)$. Application of PA decreased the soil electrical conductivity (EC) and sodium adsorption ratio (SAR) about $91 \%$ and $96 \%$ respectively after one cropping season. Grain yield had highly significant $\left(r^{2}=0.829\right)$ negative correlation with soil $\mathrm{EC}_{\mathrm{e}}$ (Electrical conductivity) whereas it was also negatively correlated with soil SAR $\left(\mathrm{r}^{2}=0.5942\right)$. Results further explained the significant positive correlation between phosphorus and iron concentration in grain $\left(r^{2}=0.7454\right)$. However, phosphorus concentration was not correlated with grain zinc concentration $\left(r^{2}=0.1798\right)$.
\end{abstract}

Keywords: Salinity, Potassium (K), Iron (Fe), P (Phosphorus), calcareous soil, grain yield.

\section{INTRODUCTION}

Salt stress is a most important threat in modern agriculture especially in arid and semiarid areas (Rahneshan et al., 2018). The soils of Pakistan are generally alkaline in nature and sodicity increases the $\mathrm{pH}$ that results in reduction of available phosphorus (P) and other nutrients in soil (Sundhari et al., 2018). On salt-affected soils, the conventional P fertilizers become inefficient and cause low yield (Sial et al., 2005; Sarwar et al., 2008). Hazardous salts accumulate in soils of arid zones, which ultimately limits the productivity of crops under such conditions. Crop yield reduces in saline and saline-sodic soils which is directly or indirectly concomitant with osmotic and specific ion effect and extent of the harmful effect is more aggravated when saline water is used for irrigation (Rahneshan et al., 2018; Nadeem et al., 2018). Availability of phosphorus in salt affected soils is minimum in saline < saline sodic < sodic soils which is due to the formation of calcium phosphate (Mahmood et al., 2013).

Lower availability of phosphorus $(\mathrm{P})$ to plants from granular $P$ fertilizers is a matter of great concern in arid and semi-arid soils owing to the presence of free lime, $\mathrm{Ca}$ and/or $\mathrm{Mg}$ (Hussain et al., 2011). Adding granular phosphatic fertilizer at normal rates and with conventional methods may not result in optimal yield (Stark and Westermann, 2003). Lesser solubility, lower mobility and comparatively higher $\mathrm{pH}$ of existing $P$ fertilizers create some hurdles to $P$ availability and uptake by plants (Rehm et al., 1998).

Organic matter is decreasing in the soil of arid regions. Adding organic fertilizers not only increase the organic matter in the soil it also improves the nutrient availability for crop. Organic matter serves as source of nutrient for plant and microorganisms which also produce the organic acids which ultimately increase the availability of nutrients through different mechanisms including chelation. In abundantly applied fertilizer P is retained by the soil and only a small portion ( 20\%) of it is taken up by the crop under alkaline soil environment (Hopkins and Ellsworth, 2005).

Phosphoric acid (PA) is a liquid fertilizer which is usually used to produce phosphatic fertilizers (Quader, 2009). Application of liquid $\mathrm{P}$ fertilizers having soil acidification effect can not only enhance crop yield in salt-affected soils but also could ameliorate such soils by lowering their $\mathrm{pH}$ and SAR. PA is a suitable source for this purpose due to its complete solubility and access down to the root zone through irrigation water (Hussain et al., 2011). 
The substances containing humic acid play a key role in recycling of nutrients (Sharif et al., 2002). Humate are used in soil or sprayed on plants (foliar application) mainly because of their maximum amount of humic acid (HA), ranging from 30 to $60 \%$ and can be taken up easily by the roots and leaves (Stevenson and Cole, 1999). Combining organic and mineral inputs has been realized as most economical for maize and soybean crops (Zingore, et al., 2007). Potassium humate (PH) is potassium salt of humic acid. It is water soluble organic substance which is used as organic fertilizer. The HA containing products are available in the form of cheap soluble salts, recognized as PH (Fong and Mat, 2007). Potassium humate decrease the abiotic stress including the salt stress by increasing the activities of different antioxidant enzymes like superoxide dismutase (SOD), catalase (CAT) and peroxidase (POD) on ginger roots (Liang et al., 2007). PH is considered to increase the permeability of plant membranes and enhance the uptake of nutrients (Shrivastava and Kumar, 2015). Keeping in mind the current problems a study was planned to evaluate the response of maize for PA and $\mathrm{PH}$ application in saline-sodic soil.

\section{MATERIAL AND METHODS}

Soil collection: An experiment was carried out in the green house of Institute of Soil and Environmental Sciences, University of Agriculture, Faisalabad to evaluate the response of maize for PA and $\mathrm{PH}$ application. Average mean temperature and humidity in the green house was $49^{\circ} \mathrm{C}$ and $30 \%$ respectively. For selection of saline sodic soil detailed soil survey was conducted by taking samples from different locations of Faisalabad including University of Agriculture, Faisalabad farms (Main campus, Chakera and Proka-II). Soil of Proka-II farm (latitude $31^{\circ} 24^{\prime} 29.87^{\prime \prime} \mathrm{N}$ and longitude $\left.72^{\circ} 58^{\prime} 53.53 " \mathrm{E}\right)$ was selected for this experiment (Table 1). The soil was comprised of 24, 11 and $65 \%$ of clay, silt and sand respectively (Table 1). Saline-sodic soil was excavated, air dried, ground and sieved $(2 \mathrm{~mm})$ and filled in twenty-seven pots@20 kg soil pot ${ }^{-1}$.

Seed sowing: There were nine treatments along with three replications. Twenty-seven plastic pots were used in the current study, which were arranged in a Completely Randomized Design. Pots were irrigated with tap water at field capacity six seeds were sown in each pot, which were germinated after 6 days. Initially 3 plants were maintained, which were thin out to one plant in each pot.

Treatment application: The experiment was conducted on maize on which recommended dose of NPK (200-150-200 kg $\mathrm{ha}^{-1}$ ) was applied, while maize hybrid Pioneer-30Y87 was used. Three level of potassium humate (Control, 50 and 100 $\mathrm{kg} \mathrm{ha}^{-1}$ ) and phosphoric acid (Control, 10 and 50\%) were used in the pot experiment.
Table 1. Physico-chemical properties of the soil.

\begin{tabular}{|c|c|c|}
\hline Soil characteristic & Unit & Value \\
\hline $\mathrm{ECe}$ & $\mathrm{dS} \mathrm{m}^{-1}$ & 7.5 \\
\hline pHs & ---- & 8.6 \\
\hline SAR & $\mathrm{mmol}_{\mathrm{c}} \mathrm{kg}^{-1}$ & 26 \\
\hline Texture & - & Sandy clay loam \\
\hline Saturation percentage & $\%$ & 30 \\
\hline Organic matter & $\%$ & 0.3 \\
\hline $\mathrm{CaCO}_{3}$ content & $\%$ & 16.4 \\
\hline $\mathrm{CO}_{3}^{--}$ & $\mathrm{meL}^{-1}$ & Nil \\
\hline $\mathrm{HCO}_{3}^{-}$ & $\mathrm{meL}^{-1}$ & 4.8 \\
\hline $\mathrm{Ca}^{++}+\mathrm{Mg}^{++}$ & $\mathrm{meL}^{-1}$ & 22.5 \\
\hline CEC & $\left(\mathrm{mmol}_{\mathrm{c}} \mathrm{kg}^{-1}\right)$ & 9.7 \\
\hline ESP & ---- & 64 \\
\hline Exc. $\mathrm{Na}^{+}$ & me $100 \mathrm{~g}^{-1}$ & 6.5 \\
\hline $\mathrm{N}$ & $\%$ & 0.03 \\
\hline $\mathrm{P}$ & $\%$ & 5.4 \\
\hline $\mathrm{K}$ & $\%$ & 73 \\
\hline $\mathrm{Fe}$ & $\mathrm{mg} \mathrm{kg}^{-1}$ & 2.46 \\
\hline $\mathrm{Zn}$ & $\mathrm{mg} \mathrm{kg}^{-1}$ & 4.37 \\
\hline $\mathrm{Cu}$ & $\mathrm{mg} \mathrm{kg}{ }^{-1}$ & 3.59 \\
\hline $\mathrm{Mn}$ & $\mathrm{mg} \mathrm{kg}^{-1}$ & 8.15 \\
\hline
\end{tabular}

$\overline{\mathrm{ECe}}=$ Electrical conductivity, $\mathrm{pHs}=\mathrm{pH}$ of soil saturated paste extract, $\mathrm{SAR}=$ Sodium Adsorption Ratio, $\mathrm{CO}_{3^{--}}=$Carbonate contents, $\mathrm{HCO}_{3}{ }^{-}=$Bicarbonate contents, $\mathrm{CEC}=$ Cation Exchange Capacity, ESP = Exchangeable Sodium Percentage, $\mathrm{N}=$ Nitrogen, $\mathrm{P}$ $=$ Phosphorus, $\mathrm{K}=$ Potassium, $\mathrm{Fe}=$ Iron, $\mathrm{Zn}=\mathrm{Zinc}, \mathrm{Cu}=$ Copper, $\mathrm{Mn}=$ Manganese

The detailed experimental plan is as under.

$\mathrm{T}_{1}=$ Control (EC-7.5+SAR-26)

$\mathrm{T}_{2}=$ Phosphoric Acid 10\% (34.88 mL 20kg-1 soil), (EC-7.5+ SAR-26)

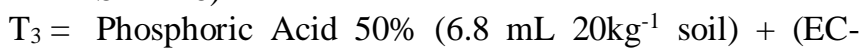
7.5+SAR-26)

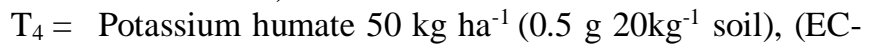
7.5+SAR-26)

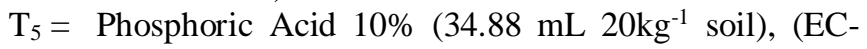
7.5+SAR-26)

$\mathrm{T}_{6}=$ Phosphoric Acid $50 \%\left(6.8 \mathrm{~mL} 20 \mathrm{~kg}^{-1}\right.$ soil $)+($ EC7.5+SAR-26)

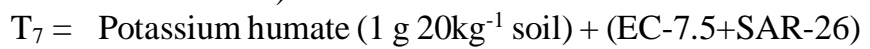

$\mathrm{T}_{8}=$ Phosphoric Acid $10 \%$ (34.88 mL 20kg $\mathrm{kg}^{-1}$ soil), (EC7.5+SAR-26)

$\mathrm{T}_{9}=$ Phosphoric Acid $50 \%$ (6.8 mL 20kg-1 soil), (EC-7. 5+SAR-26)

In first treatment saline sodic soil was used (EC-7.5+ SAR26) while Urea, SSP and SOP were added according to the recommended dose of NPK (200-150-200 kg ha-1) for hybrid maize. $\mathrm{T}_{2}$ was comprised of PA $\left(34.88 \mathrm{~mL} \mathrm{pot}^{-1}\right)$ only Urea and SOP were added in this treatment along with PA. Treatment three was different from treatment two with only difference is the increased level of PA was used in the third treatment and Urea, SOP were used according to the 
Table 2. Chemical properties of amendments.

\begin{tabular}{cccccccc}
\hline Sr. \# & Name & $\mathbf{E C}$ & $\mathbf{p H}$ & $\mathbf{C}$ & $\mathbf{N}$ & $\mathbf{P}_{\mathbf{2}} \mathbf{O}_{\mathbf{5}}$ & $\mathbf{K}_{\mathbf{2}} \mathbf{O}$ \\
\hline 1 & PA & 0.00 & 3.99 & ND & ND & $35 \%$ and $10 \%$ & ND \\
2 & PH & 0.06 & 7.78 & $32 \%$ & ND & ND & $5.2 \%$ \\
\hline
\end{tabular}

$\mathrm{PA}=$ Phosphoric acid, $\mathrm{PH}=$ Potassium humate, $\mathrm{ND}=$ Not detectable

recommended dose of $\mathrm{N}$ and $\mathrm{K}$. While the recommended dose of phosphorus was fulfilled with phosphoric acid. In treatment

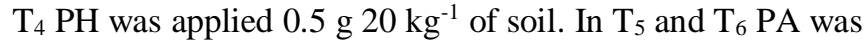

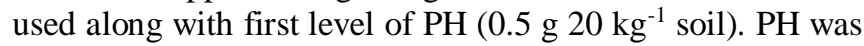

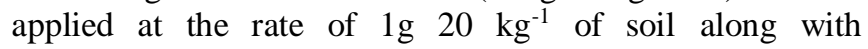
recommended dose of NPK in treatment seven. Last two treatments were comprised of both levels of PA and higher level of PH while Urea and SOP were applied according to the recommended dose of $\mathrm{N}$ and $\mathrm{K}$. Urea was applied into two splits. First split of urea was applied at sowing, while second split was applied at first irrigation which was done after two week of seed germination. Potassium humate was applied at sowing while phosphoric acid was applied at first irrigation.

Harvesting: Plant in each pot was harvested at maturity and was stored in brown paper bag. These were placed in an oven at $65^{\circ} \mathrm{C} \pm 0.5$ for 24 to $48 \mathrm{~h}$ till constant weight.

Soil physicochemical parameters: The soil was examined for different pre and post-harvest soil analysis. Soil EC and $\mathrm{pH}$ was recorded with the help of $\mathrm{EC}$ and $\mathrm{pH}$ meter. Hydrometer method (Bouyoucos, 1962) was followed for particle size analysis. For soil moisture contents approximately $100 \mathrm{~g}$ of soil saturated paste was oven-dried at $105^{\circ} \mathrm{C}$ till constant weight and SP (saturation percentage) was calculated by the equation.

$$
\text { SP }(\%)=\frac{\text { Loss in weight on oven drying }(\mathrm{g})}{\text { Oven dried soil weight }(\mathrm{g})} \times 100
$$

Exchangeable sodium percentage (ESP) of the soil was calculated using Mohsen et al. (2009) formula as follows:

$$
\mathrm{ESP}=\frac{\text { Exchangeable sodium }}{\text { Soil CEC }} \times 100
$$

Soil nitrogen was determined by kjeldhal method while $\mathrm{P}$ and $\mathrm{K}$ in soil was determined by Chapman and Parker (1961) and Olsen et al. (1954), respectively. Available micronutrients were determined by following the method of Soltanpour and Workman (1979). The extracting solution was $1 \mathrm{M}$ in the ammonium bicarbonate $\left(\mathrm{NH}_{4} \mathrm{HCO}_{3}\right)$, and $0.005 \mathrm{M}$ DTPA adjusted to $\mathrm{pH}$ 7.6. $10 \mathrm{~g}$ air dry soil $(2 \mathrm{~mm})$ was taken into a $125 \mathrm{~mL}$ conical flask. $20 \mathrm{~mL}$ extracting solution was added in it. The whole solution was shaken on a reciprocal shaker for 15 minutes at 180 cycles/minute with flasks kept open. Filter the suspension using Whatman No. 42 filter paper. The filtrate was analyzed on Atomic Absorption Spectrophotometer (Perkin- Elmer 360 Atomic Absorption Spectrophotometer).

Plant chemical analysis: Each plant sample was grounded after oven drying with the help of electric grinder. $1 \mathrm{~g}$ plant ground sample was used for further analysis.

Plant macro and micro-nutrients: Total nitrogen contents (TN) was determined by Kjeldahl method. P (Phosphorus) in tissue was determined by yellow method after digestion spectrophotometerically (BS-UV-6000). Plant samples were digested with di-acid mixture of $\mathrm{HNO}_{3}$ and $\mathrm{HClO}_{4}$ (3:1) for potassium and sodium analysis (Yoshida et al., 1976) and the data were recorded for $\mathrm{K}^{+}$and $\mathrm{Na}^{+}$concentrations by flamephotometry, while the concentration of micronutrients (Fe, $\mathrm{Zn}, \mathrm{Cu}$ and $\mathrm{Mn}$ ) was estimated by Atomic Absorption Spectrophotometer. Nutrient concentration was determined in root, soot and grain.

Growth and yield of maize: Growth (length and dry weight) and yield (grain) parameters were recorded with meter rod and Grain weight was measured by analytical balance.

Statistical analysis: All the data were analyzed statistically under CRD design with three replications. Data were interpreted by using statistical package Statistics $8.1{ }^{\circledR}$. All the results were compared by using Tukey multiple comparison test HSD.

\section{RESULTS}

Growth responses: The data regarding growth responses of maize presented in the Table 3 are significant at $P<0.05$. On an overall basis, growth parameters increased significantly with the application of both the amendments either alone or in combination under salt stress. The maximum increase in shoot dry weight was observed in $\mathrm{T}_{8}(15.12 \mathrm{~g})$ where phosphoric acid (10\%) was applied along with potassium humate $\left(100 \mathrm{~kg} \mathrm{ha}^{-1}\right)$ followed by $\mathrm{T}_{3}(13.44 \mathrm{~g})$ where phosphoric acid (50\%) was applied alone. The treatment effect of $\mathrm{T}_{2}(\mathrm{PA} 10 \%)$ and $\mathrm{T}_{9}\left(\mathrm{PA} 50 \%+\mathrm{PH} 100 \mathrm{~kg} \mathrm{ha}^{-1}\right.$ ) was not significant. Similar result was observed in $\mathrm{T}_{4}$ and $\mathrm{T}_{6}$. The application of potassium humate $\left(100 \mathrm{~kg} \mathrm{ha}^{-1}\right)$ produced significantly lowest shoot dry weight $(8.98 \mathrm{~g})$ compared to other treatments however it was more than control $(6.26 \mathrm{~g})$.

The highest shoot dry weight was found in $\mathrm{T}_{8}(241 \%)$ compared to control and other treatments on relative basis. However lowest shoot dry weight has been recorded in $\mathrm{T}_{7}$ $(143 \%)$ in which the potassium humate was applied at the rate of $100 \mathrm{~kg} \mathrm{ha}^{-1}$. Maximum root dry weight was produced by the application of phosphoric acid (50\%) along with potassium humate $\left(100 \mathrm{~kg} \mathrm{ha}^{-1}\right)$ in $\mathrm{T}_{9}$; however, it was $315 \%$ of respective control. Similarly root and shoot length were recorded maximum in $\mathrm{T}_{9}$ which were 181 and $232 \%$ of their respective control on relative basis.

Nitrogen concentration in root, shoot and grain (\%): Amount of $\mathrm{N}$ in grain, root and shoot was estimated by expressing the amount of total nitrogen in each part. Application of phosphoric acid and potassium humate had 
Table 3. Effect of phosphoric acid and potassium humate on growth of maize in saline- sodic soil.

\begin{tabular}{|c|c|c|c|c|}
\hline \multirow[t]{2}{*}{ Treatment } & \multicolumn{4}{|c|}{ Growth parameters } \\
\hline & $\begin{array}{c}\text { Shoot dry weight } \\
\left(\text { g pot }^{-1}\right)\end{array}$ & $\begin{array}{c}\text { Root dry weight } \\
\left(\text { g pot }^{-1}\right)\end{array}$ & $\begin{array}{c}\text { Shoot length } \\
(\mathrm{cm})\end{array}$ & $\begin{array}{c}\text { Root length } \\
(\mathbf{c m})\end{array}$ \\
\hline $\mathrm{T}_{1}$ & $6.26 \pm 0.53$ & $0.51 \pm 0.07$ & $44.3 \pm 2.05$ & $24.3 \pm 1.45$ \\
\hline $\mathrm{T}_{2}$ & $12.65 \pm 0.92(202)$ & $1.08 \pm 0.06(212)$ & $68.7 \pm 1.19(155)$ & $33.3 \pm 2.14(137)$ \\
\hline $\mathrm{T}_{3}$ & $13.44 \pm 0.60(215)$ & $1.18 \pm 0.10(231)$ & $68.0 \pm 1.78(153)$ & $37.1 \pm 2.21(153)$ \\
\hline $\mathrm{T}_{4}$ & $9.48 \pm 1.06(151)$ & $0.96 \pm 0.08$ & $70.7 \pm 1.86(160)$ & $29.4 \pm 1.29(121)$ \\
\hline $\mathrm{T}_{5}$ & $11.63 \pm 1.17(186)$ & $1.29 \pm 0.10(253)$ & $77.0 \pm 2.31(174)$ & $41.2 \pm 2.01(170)$ \\
\hline $\mathrm{T}_{6}$ & $9.29 \pm 0.94(148)$ & $1.37 \pm 0.12(269)$ & $71.7 \pm 1.70(162)$ & $46.8 \pm 0.52(193)$ \\
\hline $\mathrm{T}_{7}$ & $8.98 \pm 0.15(143)$ & $1.10 \pm 0.09(216)$ & $62.3 \pm 2.32(141)$ & $31.6 \pm 1.73(130)$ \\
\hline $\mathrm{T}_{8}$ & $15.12 \pm 1.17(242)$ & $1.38 \pm 0.11(271)$ & $67.3 \pm 1.77(152)$ & $51.2 \pm 1.07(211)$ \\
\hline $\mathrm{T}_{9}$ & $12.17 \pm 1.45$ & $1.60 \pm 0.08(314)$ & $80.3 \pm 1.53(181)$ & $56.5 \pm 0.50(233)$ \\
\hline Mean & 11.00 & 1.16 & 67.9 & 39.0 \\
\hline HSD & 5.06 & 0.46 & 9.42 & 7.75 \\
\hline
\end{tabular}

Each value is an average of three values \pm S.E., while value in () is the $\%$ of respective control; $\mathrm{T}_{1}=\mathrm{Control}, \mathrm{T}_{2}=\mathrm{Phosphoric}$ acid $(34.88$ $\mathrm{mL}), \mathrm{T}_{3}=$ Phosphoric acid $(6.8 \mathrm{~mL}), \mathrm{T}_{4}=$ Potassium humate $(0.5 \mathrm{~g}), \mathrm{T}_{5}=$ Phosphoric acid $(34.88 \mathrm{~mL})+$ Potassium humate $(0.5 \mathrm{~g}), \mathrm{T}_{6}=$ Phosphoric Acid $(6.8 \mathrm{~mL})+$ Potassium humate $(0.5 \mathrm{~g}), \mathrm{T}_{7}=$ Potassium humate $(1 \mathrm{~g}), \mathrm{T}_{8}=$ Phosphoric Acid $(34.88 \mathrm{~mL})+$ Potassium humate $(1 \mathrm{~g}), \mathrm{T}_{9}=$ Phosphoric Acid $(6.8 \mathrm{~mL})+$ Potassium humate $(1 \mathrm{~g})$

Table 4. Effect of phosphoric acid and potassium humate on ionic analysis of maize in saline-sodic soil.

\begin{tabular}{|c|c|c|c|}
\hline \multirow[t]{2}{*}{ Treatments } & \multicolumn{3}{|c|}{ Nitrogen concentration (\%) } \\
\hline & Root & Shoot & Grain \\
\hline $\mathrm{T}_{1}$ & $0.39 \pm 0.03$ & $0.45 \pm 0.04$ & $0.52 \pm 0.03$ \\
\hline $\mathrm{T}_{2}$ & $0.60 \pm 0.04(154)$ & $0.62 \pm 0.02(138)$ & $0.73 \pm 0.03(140)$ \\
\hline $\mathrm{T}_{3}$ & $0.68 \pm 0.02(174)$ & $0.71 \pm 0.02(158)$ & $0.83 \pm 0.02(160)$ \\
\hline $\mathrm{T}_{4}$ & $0.94 \pm 0.06(241)$ & $1.06 \pm 0.03(236)$ & $1.14 \pm 0.02(219)$ \\
\hline $\mathrm{T}_{5}$ & $1.21 \pm 0.07(310)$ & $1.30 \pm 0.04(289)$ & $1.50 \pm 0.05(288)$ \\
\hline $\mathrm{T}_{6}$ & $1.14 \pm 0.05(292)$ & $1.26 \pm 0.03(280)$ & $1.42 \pm 0.04(273)$ \\
\hline $\mathrm{T}_{7}$ & $0.78 \pm 0.03(200)$ & $0.91 \pm 0.05(202)$ & $1.03 \pm 0.03(198)$ \\
\hline $\mathrm{T}_{8}$ & $1.05 \pm 0.05(269)$ & $1.18 \pm 0.03(262)$ & $1.37 \pm 0.02(263)$ \\
\hline $\mathrm{T}_{9}$ & $0.82 \pm 0.04(210)$ & $1.01 \pm 0.05(224)$ & $1.10 \pm 0.03(212)$ \\
\hline Mean & 0.84 & 0.95 & 1.07 \\
\hline HSD & 0.2337 & 0.1742 & 0.1546 \\
\hline
\end{tabular}

Each value is an average of three values \pm S.E. while value in () is the $\%$ of respective control; $\mathrm{T}_{1}=\mathrm{Control}, \mathrm{T}_{2}=\mathrm{Phosphoric}$ acid $(34.88$ $\mathrm{mL}), \mathrm{T}_{3}=$ Phosphoric acid $(6.8 \mathrm{~mL}), \mathrm{T}_{4}=$ Potassium humate $(0.5 \mathrm{~g}), \mathrm{T}_{5}=$ Phosphoric acid $(34.88 \mathrm{~mL})+$ Potassium humate $(0.5 \mathrm{~g}), \mathrm{T}_{6}=$ Phosphoric acid $(6.8 \mathrm{~mL})+$ Potassium humate $(0.5 \mathrm{~g}), \mathrm{T}_{7}=$ Potassium humate $(1 \mathrm{~g}), \mathrm{T}_{8}=$ Phosphoric acid $(34.88 \mathrm{~mL})+$ Potassium humate $(1 \mathrm{~g}), \mathrm{T}_{9}=$ Phosphoric acid $(6.8 \mathrm{~mL})+$ Potassium humate $(1 \mathrm{~g})$

noteworthy effect on nitrogen quantity in all the plant parts. The greatest nitrogen concentration was recorded in $\mathrm{T}_{5}$ in root $(1.21 \%)$ shoot $(1.30 \%)$ and grain $(1.50 \%)$ (Table 4$)$. Nitrogen root concentration was minimum in $\mathrm{T}_{2}(0.60 \%)$ however it was more than control $(0.39 \%)$. There was more than 270 times increase in nitrogen concentration in root, shoot and grain on relative basis. Nitrogen concentration was found more in grain followed by shoot and root. Data clearly indicated that with combined application of both the amendments nitrogen uptake was maximum as compared to control. In contrast to root, alone application of phosphoric acid had no significant effect on nitrogen in grain and shoot. Similar results were recorded in $\mathrm{T}_{4}$ and $\mathrm{T}_{9}$ for $\mathrm{N}$ shoot concentration and between $T_{4}, T_{7}$ and $T_{9}$ which were similar relative to each other.
Phosphorus concentration in root, shoot and grain (\%): The quantity of $\mathrm{P}$ was significantly affected at $\mathrm{P}<0.05$. $\mathrm{PA}$ alone application influenced the $\mathrm{P}$ in all the plant parts (root, shoot and grain). Application of PA (50\%) significantly showed higher $\mathrm{P}$ in root $(0.42 \%)$, shoot $(0.39 \%)$ and grain $(0.46 \%)$ followed by $\mathrm{T}_{2}$ (phosphoric acid 10\%) (Table 5). Overall $\mathrm{P}$ concentration was maximum in grain and root. $\mathrm{PH}\left(100 \mathrm{~kg} \mathrm{ha}^{-}\right.$ ${ }^{1}$ ) had not showed a significant P concentration in root, shoot and grain. Its relative performance was $113 \%$ than control. However, this response was less than all other treatments. Maximum relative response for $\mathrm{P}$ concentration in root (280\%), shoot (279\%) and grain (271\%) was more than 250 times than un-amended control $\left(\mathrm{T}_{1}\right)$.

Potassium concentration in root, shoot and grain (\%): Maize potassium concentration was significantly influenced 
Mitigation of salt stress in maize

Table 5. Effect of phosphoric acid and potassium humate on ionic analysis of maize in saline-sodic soil.

\begin{tabular}{lccc}
\hline Treatments & \multicolumn{3}{c}{ Phosphorus concentration (\%) } \\
\cline { 2 - 4 } & Root & Shoot & Grain \\
\hline $\mathrm{T}_{1}$ & $0.15 \pm 0.04$ & $0.14 \pm 0.02$ & $0.17 \pm 0.03$ \\
$\mathrm{~T}_{2}$ & $0.38 \pm 0.01(253)$ & $0.35 \pm 0.02(250)$ & $0.41 \pm 0.02(241)$ \\
$\mathrm{T}_{3}$ & $0.42 \pm 0.03(280)$ & $0.39 \pm 0.03(279)$ & $0.46 \pm 0.02(271)$ \\
$\mathrm{T}_{4}$ & $0.21 \pm 0.03(140)$ & $0.19 \pm 0.02(136)$ & $0.23 \pm 0.03(135)$ \\
$\mathrm{T}_{5}$ & $0.31 \pm 0.02(207)$ & $0.28 \pm 0.03(200)$ & $0.33 \pm 0.01(194)$ \\
$\mathrm{T}_{6}$ & $0.34 \pm 0.01(227)$ & $0.31 \pm 0.02(221)$ & $0.37 \pm 0.03(218)$ \\
$\mathrm{T}_{7}$ & $0.17 \pm 0.02(113)$ & $0.16 \pm 0.03(114)$ & $0.21 \pm 0.02(124)$ \\
$\mathrm{T}_{8}$ & $0.28 \pm 0.04(187)$ & $0.25 \pm 0.03(179)$ & $0.31 \pm 0.02(182)$ \\
$\mathrm{T}_{9}$ & $0.24 \pm 0.03(160)$ & $0.21 \pm 0.03(150)$ & $0.28 \pm 0.02(165)$ \\
\hline Mean & 0.28 & 0.25 & 0.31 \\
\hline HSD & 0.1261 & 0.1214 & 0.0986 \\
\hline
\end{tabular}

Each value is an average of three values \pm S.E., while value in () is the $\%$ of respective control; $\mathrm{T}_{1}=\mathrm{Control}, \mathrm{T}_{2}=\mathrm{Phosphoric}$ acid $(34.88$ $\mathrm{mL}), \mathrm{T}_{3}=$ Phosphoric acid $(6.8 \mathrm{~mL}), \mathrm{T}_{4}=$ Potassium humate $(0.5 \mathrm{~g}), \mathrm{T}_{5}=$ Phosphoric acid $(34.88 \mathrm{~mL})+$ Potassium humate $(0.5 \mathrm{~g}), \mathrm{T}_{6}=$ Phosphoric Acid $(6.8 \mathrm{~mL})+$ Potassium humate $(0.5 \mathrm{~g}), \mathrm{T}_{7}=$ Potassium humate $(1 \mathrm{~g}), \mathrm{T}_{8}=$ Phosphoric acid $(34.88 \mathrm{~mL})+$ Potassium humate $(1 \mathrm{~g}), \mathrm{T}_{9}=$ Phosphoric acid $(6.8 \mathrm{~mL})+$ Potassium humate $(1 \mathrm{~g})$

Table 6. Effect of phosphoric acid and potassium humate on ionic analysis of maize in saline-sodic soil.

\begin{tabular}{|c|c|c|c|}
\hline \multirow[t]{2}{*}{ Treatments } & \multicolumn{3}{|c|}{ Potassium concentration (\%) } \\
\hline & Root & Shoot & Grain \\
\hline $\mathrm{T}_{1}$ & $2.75 \pm 0.05$ & $2.31 \pm 0.03$ & $2.84 \pm 0.03$ \\
\hline $\mathrm{T}_{2}$ & $3.31 \pm 0.04(120)$ & $2.67 \pm 0.03(116)$ & $3.32 \pm 0.04(117)$ \\
\hline $\mathrm{T}_{3}$ & $3.35 \pm 0.05(122)$ & $3.15 \pm 0.04(136)$ & $3.75 \pm 0.03(132)$ \\
\hline $\mathrm{T}_{4}$ & $4.17 \pm 0.03(152)$ & $3.71 \pm 0.03(161)$ & $4.26 \pm 0.05(150)$ \\
\hline $\mathrm{T}_{5}$ & $3.77 \pm 0.02(137)$ & $3.44 \pm 0.05(149)$ & $3.87 \pm 0.03(136)$ \\
\hline $\mathrm{T}_{6}$ & $3.82 \pm 0.02(139)$ & $3.57 \pm 0.04(155)$ & $3.94 \pm 0.03(139)$ \\
\hline $\mathrm{T}_{7}$ & $3.89 \pm 0.04(141)$ & $3.64 \pm 0.01(158)$ & $3.97 \pm 0.02(140)$ \\
\hline $\mathrm{T}_{8}$ & $3.71 \pm 0.03(135)$ & $3.39 \pm 0.04(147)$ & $3.84 \pm 0.02(135)$ \\
\hline $\mathrm{T}_{9}$ & $3.63 \pm 0.02(132)$ & $3.32 \pm 0.02(144)$ & $3.80 \pm 0.03(134)$ \\
\hline Mean & 3.60 & 3.24 & 3.73 \\
\hline HSD & 0.1700 & 0.1657 & 0.1471 \\
\hline
\end{tabular}

Each value is an average of three values \pm standard error while value in () is the $\%$ of respective control; $\mathrm{T}_{1}=\mathrm{Control}, \mathrm{T}_{2}=\mathrm{Phosphoric}$ acid $(34.88 \mathrm{~mL}), \mathrm{T}_{3}=$ Phosphoric acid $(6.8 \mathrm{~mL}), \mathrm{T}_{4}=$ Potassium humate $(0.5 \mathrm{~g}), \mathrm{T}_{5}=$ Phosphoric acid $(34.88 \mathrm{~mL})+$ Potassium humate $(0.5 \mathrm{~g}), \mathrm{T}_{6}=$ Phosphoric Acid $(6.8 \mathrm{~mL})+$ Potassium humate $(0.5 \mathrm{~g}), \mathrm{T}_{7}=$ Potassium humate $(1 \mathrm{~g}), \mathrm{T}_{8}=$ Phosphoric acid $(34.88 \mathrm{~mL})+$ Potassium humate $(1 \mathrm{~g}), \mathrm{T}_{9}=$ Phosphoric acid $(6.8 \mathrm{~mL})+$ Potassium humate $(1 \mathrm{~g})$

by the potassium humate and phosphoric acid treatment. Comparison showed that potassium concentration was more in grain followed by root and shoot. Potassium humate $(50 \mathrm{~kg}$ $\mathrm{ha}^{-1}$ ) showed maximum potassium concentration in root $(4.17 \%)$, shoot $(3.71 \%)$ and grain $(4.26 \%)$. Further increase in potassium humate application had reduced the potassium concentration in all the plant parts.

Alone application of both the amendments showed significant response for potassium concentration as compared to their combined application. Minimum potassium concentration was recorded in un-amended control for root $(2.75 \%)$, shoot $(2.31 \%)$ and grain $(2.84 \%)$. Data (Table 6) showed maximum $\mathrm{K}^{+}$quantity in shoot $(161 \%)$, root $(152 \%)$, and grain $(150 \%)$ relative to control.

Micronutrients concentration in root, shoot and grain (mg $\mathbf{k g}^{-1}$ ): In comparison to other micronutrients, iron concentration was significantly affected with phosphoric acid application which was more as compare to potassium humate alone or in combination $(\mathrm{P}<0.05)$. Iron concentration was recorded maximum in maize root $\left(60.11 \mathrm{mg} \mathrm{kg}^{-1}\right)$ followed by shoot (62.38 $\mathrm{mg} \mathrm{kg}^{-1}$ ) and grain (64.42 $\mathrm{mg} \mathrm{kg}^{-1}$ ) (Table 7). PA (50\%) along with $\mathrm{PH}\left(100 \mathrm{~kg} \mathrm{ha}^{-1}\right)$ resulted maximum iron concentration in root (171\%), shoot (165\%) and grain (192\%) on relative basis. Results revealed that combined application of PA (50\%) and PH (50 kg ha $\left.{ }^{-1}\right)$ displayed the maximum zinc concentration in grain $\left(37.27 \mathrm{mg} \mathrm{kg}^{-1}\right)$ followed by shoot (31.18 $\left.\mathrm{mg} \mathrm{kg}^{-1}\right)$ and root $\left(30.74 \mathrm{mg} \mathrm{kg}^{-1}\right)$. Relative zinc concentration in root (365\%), shoot (493\%) and grain (333\%) was observed in $\mathrm{T}_{6}$ (Table 7). Results (Table 8) further indicated that copper and manganese had not generalized response in root, shoot and grain. However, maximum copper value in root $\left(9.52 \mathrm{mg} \mathrm{kg}^{-1}\right)$ and shoot $\left(12.46 \mathrm{mg} \mathrm{kg}^{-1}\right)$ was 
Table 7. Effect of phosphoric acid and potassium humate on ionic analysis (Fe and $\mathrm{Zn}$ ) of maize in saline-sodic soil.

\begin{tabular}{|c|c|c|c|c|c|c|}
\hline \multirow[t]{2}{*}{ Treatments } & \multicolumn{3}{|c|}{ Fe (ppm) } & \multicolumn{3}{|c|}{ Zn (ppm) } \\
\hline & Root & Shoot & Grain & Root & Shoot & Grain \\
\hline $\mathrm{T}_{1}$ & $35.17 \pm 2.12$ & $37.92 \pm 1.89$ & $33.63 \pm 2.55$ & $8.42 \pm 1.24$ & $6.33 \pm 1.06$ & $11.19 \pm 1.63$ \\
\hline $\mathrm{T}_{2}$ & $\begin{array}{c}38.12 \pm 2.09 \\
(108)\end{array}$ & $\begin{array}{c}40.93 \pm 2.44 \\
(108)\end{array}$ & $41.14 \pm 2.24$ & $\begin{array}{c}11.26 \pm 0.95 \\
(134)\end{array}$ & $\begin{array}{c}11.03 \pm 1.91 \\
(174)\end{array}$ & $14.39 \pm 1.47$ \\
\hline $\mathrm{T}_{3}$ & $\begin{array}{c}41.25 \pm 1.44 \\
(117)\end{array}$ & $\begin{array}{c}44.27 \pm 2.66 \\
(117)\end{array}$ & $\begin{array}{c}51.83 \pm 1.50 \\
(154)\end{array}$ & $\begin{array}{c}14.16 \pm 1.46 \\
(168)\end{array}$ & $\begin{array}{c}13.15 \pm 1.91 \\
(208)\end{array}$ & $\begin{array}{c}25.42 \pm 1.18 \\
(227)\end{array}$ \\
\hline $\mathrm{T}_{4}$ & $\begin{array}{c}42.33 \pm 1.42 \\
(120)\end{array}$ & $\begin{array}{c}45.77 \pm 2.06 \\
(121)\end{array}$ & $\begin{array}{c}48.61 \pm 1.68 \\
(145)\end{array}$ & $\begin{array}{c}24.82 \pm 1.25 \\
(295)\end{array}$ & $\begin{array}{c}21.75 \pm 1.53 \\
(344)\end{array}$ & $\begin{array}{c}27.18 \pm 1.84 \\
(243)\end{array}$ \\
\hline $\mathrm{T}_{5}$ & $\begin{array}{c}58.13 \pm 2.56 \\
(165)\end{array}$ & $\begin{array}{c}50.28 \pm 1.47 \\
(133)\end{array}$ & $\begin{array}{c}53.28 \pm 2.17 \\
(158)\end{array}$ & $\begin{array}{c}27.19 \pm 1.40 \\
(323)\end{array}$ & $\begin{array}{c}28.16 \pm 1.52 \\
(445)\end{array}$ & $\begin{array}{c}28.16 \pm 1.82 \\
(252)\end{array}$ \\
\hline $\mathrm{T}_{6}$ & $\begin{array}{c}51.28 \pm 0.69 \\
(146)\end{array}$ & $\begin{array}{c}53.22 \pm 1.54 \\
(140)\end{array}$ & $\begin{array}{c}64.42 \pm 1.77 \\
(192)\end{array}$ & $\begin{array}{c}30.74 \pm 1.48 \\
(365)\end{array}$ & $\begin{array}{c}31.18 \pm 1.57 \\
(493)\end{array}$ & $\begin{array}{c}37.27 \pm 1.16 \\
(333)\end{array}$ \\
\hline $\mathrm{T}_{7}$ & $\begin{array}{c}37.94 \pm 2.62 \\
(108)\end{array}$ & $\begin{array}{c}40.12 \pm 1.40 \\
(106)\end{array}$ & $\begin{array}{c}50.72 \pm 1.68 \\
(151)\end{array}$ & $\begin{array}{c}26.42 \pm 1.60 \\
(314)\end{array}$ & $\begin{array}{c}25.83 \pm 2.33 \\
(408)\end{array}$ & $\begin{array}{c}30.46 \pm 2.15 \\
(272)\end{array}$ \\
\hline $\mathrm{T}_{8}$ & $\begin{array}{c}60.11 \pm 3.55 \\
(171)\end{array}$ & $\begin{array}{c}62.38 \pm 1.21 \\
(165)\end{array}$ & $\begin{array}{c}64.23 \pm 1.54 \\
(191)\end{array}$ & $\begin{array}{c}21.94 \pm 1.10 \\
(261)\end{array}$ & $\begin{array}{c}18.35 \pm 2.22 \\
(290)\end{array}$ & $\begin{array}{c}25.28 \pm 1.47 \\
(226)\end{array}$ \\
\hline $\mathrm{T}_{9}$ & $\begin{array}{c}57.13 \pm 2.69 \\
(162)\end{array}$ & $\begin{array}{c}58.94 \pm 2.34 \\
(155)\end{array}$ & $\begin{array}{c}61.29 \pm 1.44 \\
(182)\end{array}$ & $\begin{array}{c}18.42 \pm 1.47 \\
(219)\end{array}$ & $\begin{array}{c}16.15 \pm 1.56 \\
(255)\end{array}$ & $\begin{array}{c}32.62 \pm 1.28 \\
(292)\end{array}$ \\
\hline Mean & 46.83 & 48.20 & 52.13 & 20.37 & 19.10 & 25.77 \\
\hline HSD & 11.286 & 9.6678 & 9.2948 & 6.6475 & 8.7977 & 7.8554 \\
\hline
\end{tabular}

Table 8. Effect of phosphoric acid and potassium humate on ionic analysis ( $\mathrm{Cu}$ and $\mathrm{Mn}$ ) of maize in saline-sodic soil.

\begin{tabular}{lcccccc}
\hline Treatments & \multicolumn{3}{c}{ Cu (ppm) } & \multicolumn{3}{c}{ Mn (ppm) } \\
\cline { 2 - 6 } & Root & Shoot & Grain & Root & Shoot & Grain \\
\hline $\mathrm{T}_{1}$ & $0.95 \pm 0.20$ & $0.98 \pm 0.04$ & $1.24 \pm 0.48$ & $3.83 \pm 0.35$ & $2.31 \pm 1.05$ & $2.11 \pm 0.44$ \\
$\mathrm{~T}_{2}$ & $1.05 \pm 0.19$ & $1.77 \pm 0.59$ & $2.27 \pm 0.23$ & $6.13 \pm 0.90$ & $6.25 \pm 0.87$ & $3.42 \pm 0.91$ \\
& $(111)$ & $(181)$ & $(183)$ & $(160)$ & $(271)$ & $(162)$ \\
$\mathrm{T}_{3}$ & $1.77 \pm 0.68$ & $2.59 \pm 0.45$ & $3.16 \pm 0.29$ & $8.37 \pm 1.18$ & $5.14 \pm 1.47$ & $3.04 \pm 1.16$ \\
& $(186)$ & $(264)$ & $(255)$ & $(219)$ & $(223)$ & $(144)$ \\
$\mathrm{T}_{4}$ & $9.52 \pm 0.51$ & $12.46 \pm 1.24$ & $8.16 \pm 0.57$ & $15.51 \pm 1.60$ & $11.29 \pm 2.13$ & $8.27 \pm 0.93$ \\
& $(1002)$ & $(1271)$ & $(658)$ & $(405)$ & $(489)$ & $(392)$ \\
$\mathrm{T}_{5}$ & $3.12 \pm 0.60$ & $4.17 \pm 0.56$ & $5.88 \pm 0.31$ & $18.29 \pm 1.09$ & $16.37 \pm 2.12$ & $11.74 \pm 1.31$ \\
& $(328)$ & $(426)$ & $(474)$ & $(478)$ & $(709)$ & $(556)$ \\
$\mathrm{T}_{6}$ & $4.22 \pm 0.83$ & $6.38 \pm 0.58$ & $7.26 \pm 0.53$ & $17.31 \pm 0.77$ & $13.88 \pm 0.97$ & $9.45 \pm 0.90$ \\
& $(444)$ & $(651)$ & $(585)$ & $(452)$ & $(601)$ & $(448)$ \\
$\mathrm{T}_{7}$ & $5.82 \pm 0.25$ & $9.53 \pm 0.95$ & $12.24 \pm 0.89$ & $13.19 \pm 1.03$ & $9.52 \pm 1.37$ & $7.93 \pm 0.73$ \\
& $(613)$ & $(972)$ & $(987)$ & $(344)$ & $(412)$ & $(376)$ \\
$\mathrm{T}_{8}$ & $7.04 \pm 0.90$ & $8.74 \pm 0.67$ & $5.13 \pm 0.61$ & $11.37 \pm 1.45$ & $9.24 \pm 2.10$ & $5.34 \pm 1.49$ \\
& $(741)$ & $(892)$ & $(414)$ & $(297)$ & $(400)$ & $(253)$ \\
$\mathrm{T}_{9}$ & $7.32 \pm 0.36$ & $8.16 \pm 0.55$ & $3.95 \pm 0.21$ & $10.82 \pm 0.98$ & $7.64 \pm 1.44$ & $5.11 \pm 1.01$ \\
& $(771)$ & $(833)$ & $(319)$ & $(283)$ & $(331)$ & $(242)$ \\
\hline Mean & 4.53 & 6.09 & 5.48 & 11.65 & 9.07 & 6.27 \\
\hline HSD & 2.7808 & 3.4610 & 2.4920 & 5.4197 & 7.8068 & 5.1041 \\
\hline
\end{tabular}

Each value is an average of three values \pm standard error while value in () is the \% of respective control; $\mathrm{T}_{1}=\mathrm{Control}_{2} \mathrm{~T}_{2}=\mathrm{Phosphoric}$ acid $(34.88 \mathrm{~mL}), \mathrm{T}_{3}=$ Phosphoric acid $(6.8 \mathrm{~mL}), \mathrm{T}_{4}=$ Potassium humate $(0.5 \mathrm{~g}) \mathrm{T}_{5}=$ Phosphoric acid $(34.88 \mathrm{~mL})+$ Potassium humate $(0.5 \mathrm{~g}), \mathrm{T}_{6}=$ Phosphoric Acid $(6.8 \mathrm{~mL})+$ Potassium humate $(0.5 \mathrm{~g}), \mathrm{T}_{7}=$ Potassium humate $(1 \mathrm{~g}), \mathrm{T}_{8}=$ Phosphoric Acid $(34.88 \mathrm{~mL})+$ Potassium humate (1g), $\mathrm{T}_{9}=$ Phosphoric Acid $(6.8 \mathrm{~mL})+$ Potassium humate $(1 \mathrm{~g})$

recorded in treatment $\mathrm{T}_{4}$ which showed the $1002 \%$ and $1271 \%$ response relative to control. While grain copper contents (12.24 mg kg $\mathrm{g}^{-1}$ ) was recorded in $\mathrm{T}_{7}$. Application of PA (10\%) along with PH (50 kg ha-1) showed maximum $\mathrm{Mn}$ concentration in root $\left(18.29 \mathrm{mg} \mathrm{kg}^{-1}\right)$, shoot $\left(16.37 \mathrm{mg} \mathrm{kg}^{-1}\right)$ and grain $\left(11.74 \mathrm{mg} \mathrm{kg}^{-1}\right)$ being $478 \%, 709 \%$ and $555 \%$ on relative basis (Table 8 ).

Grain yield ( $\left(\right.$ pot $\left.^{-1}\right)$ : The data presented in Table 9 describe the significant relationship among different treatments $(\mathrm{P}<0.05)$. Grain yield was maximum in $\mathrm{T}_{8}(34.76 \mathrm{~g})$ followed 
by $\mathrm{T}_{9}(32.60 \mathrm{~g})$, while the minimum grain yield $(27.11 \mathrm{~g})$ was recorded in $\mathrm{T}_{2}$. However, it was more than control (17.66 g). It was clear from the data that maximum relative performance of $\mathrm{T}_{8}$ for grain yield was recorded as $197 \%$. Grain yield was significantly positively correlated $\left(\mathrm{r}^{2}=0.6618\right)$ at $5 \%$ level with shoot dry weight. Figure 1 showed that grain yield increased significantly with the increase in shoot dry weight.

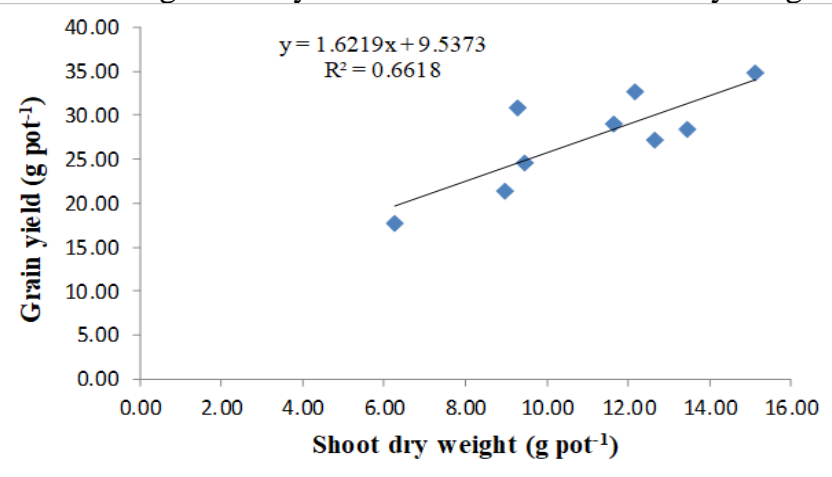

Figure 1. Correlation between shoot dry weight and grain yield.

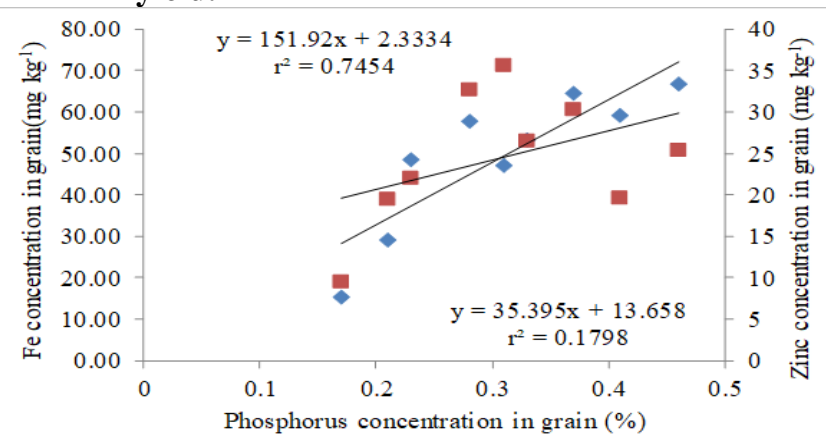

Figure 2. Correlation between phosphorus, zinc and iron concentration in grain.
Table 9. Effect of phosphoric acid and potassium humate on yield attributes of maize in saline-sodic soil.

\begin{tabular}{lc}
\hline Treatments & Grain yield $\left(\mathbf{g ~ p o t}^{-1}\right)$ \\
\hline $\mathrm{T}_{1}$ & $17.66 \pm 1.57$ \\
$\mathrm{~T}_{2}$ & $27.11 \pm 2.06(154)$ \\
$\mathrm{T}_{3}$ & $28.42 \pm 1.82(161)$ \\
$\mathrm{T}_{4}$ & $24.63 \pm 2.92(139)$ \\
$\mathrm{T}_{5}$ & $28.97 \pm 1.90(164)$ \\
$\mathrm{T}_{6}$ & $30.86 \pm 2.08(175)$ \\
$\mathrm{T}_{7}$ & $21.42 \pm 1.47(121)$ \\
$\mathrm{T}_{8}$ & $34.76 \pm 2.13(197)$ \\
$\mathrm{T}_{9}$ & $32.60 \pm 1.91(185)$ \\
\hline Mean & 27.38 \\
\hline HSD Tuckey Value & 10.024 \\
\hline
\end{tabular}

Each value is an average of three values \pm standard error while value in () is the $\%$ of respective control, $\mathrm{T}_{1}=$ Control, $\mathrm{T}_{2}=$ Phosphoric acid $(34.88 \mathrm{~mL}), \mathrm{T}_{3}=$ Phosphoric acid $(6.8 \mathrm{~mL}), \mathrm{T}_{4}=$ Potassium humate $(0.5 \mathrm{~g}), \mathrm{T}_{5}=$ Phosphoric acid $(34.88 \mathrm{~mL})+$ Potassium humate $(0.5 \mathrm{~g}), \mathrm{T}_{6}=$ Phosphoric Acid $(6.8 \mathrm{~mL})+$ Potassium humate $(0.5 \mathrm{~g})$, $\mathrm{T}_{7}=$ Potassium humate $(1 \mathrm{~g}), \mathrm{T}_{8}=$ Phosphoric Acid $(34.88 \mathrm{~mL})+$ Potassium humate (1g), $\mathrm{T}_{9}=$ Phosphoric Acid $(6.8 \mathrm{~mL})+$ Potassium humate $(1 \mathrm{~g})$

Post-harvest soil analysis (Soil ECe, pHs and SAR): Postharvest soil $\mathrm{EC}_{\mathrm{e}}$ was significantly $(\mathrm{P}<0.05)$ different among treatments (Table 10). The maximum decrease in soil $\mathrm{EC}_{\mathrm{e}}$ was recorded in $T_{3}$ (6.72). This reduction was followed by $T_{2}$ (6.94). The soil $\mathrm{pH}$ differed non-significantly because of amendments. It was maximum in control (8.59) followed by $\mathrm{T}_{5}$ (8.54). There was $85 \%$ reduction in $\mathrm{EC}_{\mathrm{e}}$ relative to control. Soil SAR was also significantly different $(\mathrm{P}<0.05)$. However, application of PA $(50 \%)$ decreased the SAR as compared to the combined application of both the amendments. Maximum decrease in SAR was recorded in in $\mathrm{T}_{3}$ (21.24) as compared to control, this reduction was about $82 \%$ on relative basis.

Table 10. Effect of phosphoric acid and potassium humate on post-harvest soil properties of saline-sodic soil.

\begin{tabular}{|c|c|c|c|}
\hline \multirow{2}{*}{ Treatments } & \multicolumn{3}{|c|}{ Post-Harvest Soil Analysis } \\
\hline & ECe $\left(\mathrm{dS} \mathrm{m}^{-1}\right)$ & $\mathrm{pHs}$ & SAR $\left(\mathrm{mmol} \mathrm{L}^{-1}\right)$ \\
\hline $\mathrm{T}_{1}$ & $7.89 \pm 0.04$ & $8.59 \pm 0.03$ & $26.00 \pm 0.36$ \\
\hline $\mathrm{T}_{2}$ & $6.94 \pm 0.07(88)$ & $8.46 \pm 0.03(98)$ & $22.33 \pm 0.61(86)$ \\
\hline $\mathrm{T}_{3}$ & $6.72 \pm 0.17(85)$ & $8.42 \pm 0.04(98)$ & $21.24 \pm 0.15(82)$ \\
\hline $\mathrm{T}_{4}$ & $7.55 \pm 0.22(96)$ & $8.52 \pm 0.02(99)$ & $24.33 \pm 0.57(94)$ \\
\hline $\mathrm{T}_{5}$ & $7.19 \pm 0.13(91)$ & $8.54 \pm 0.03(99)$ & $22.92 \pm 0.26(88)$ \\
\hline $\mathrm{T}_{6}$ & $7.36 \pm 0.31(93)$ & $8.52 \pm 0.04(99)$ & $23.36 \pm 0.39(90)$ \\
\hline $\mathrm{T}_{7}$ & $7.69 \pm 0.08(97)$ & $8.50 \pm 0.02(99)$ & $24.00 \pm 0.18(92)$ \\
\hline $\mathrm{T}_{8}$ & $7.28 \pm 0.06(92)$ & $8.48 \pm 0.02(99)$ & $23.67 \pm 0.16(91)$ \\
\hline $\mathrm{T}_{9}$ & $7.44 \pm 0.13(94)$ & $8.43 \pm 0.06(98)$ & $23.16 \pm 0.36(89)$ \\
\hline Mean value & 7.34 & 8.49 & 23.13 \\
\hline HSD Value & 0.7739 & 0.1737 & 1.8603 \\
\hline
\end{tabular}

Each value is an average of three values \pm standard error while value in () is the $\%$ of respective control; $\mathrm{T}_{1}=\mathrm{Control}, \mathrm{T}_{2}=\mathrm{Phosphoric}$ acid $(34.88 \mathrm{~mL}), \mathrm{T}_{3}=$ Phosphoric acid $(6.8 \mathrm{~mL}), \mathrm{T}_{4}=$ Potassium humate $(0.5 \mathrm{~g}), \mathrm{T}_{5}=$ Phosphoric acid $(34.88 \mathrm{~mL})+$ Potassium humate $(0.5 \mathrm{~g}), \mathrm{T}_{6}=$ Phosphoric acid $(6.8 \mathrm{~mL})+$ Potassium humate, $(0.5 \mathrm{~g}), \mathrm{T}_{7}=$ Potassium humate $(1 \mathrm{~g}), \mathrm{T}_{8}=$ Phosphoric acid $(34.88 \mathrm{~mL})+$ Potassium humate $(1 \mathrm{~g}), \mathrm{T}_{9}=$ Phosphoric acid $(6.8 \mathrm{~mL})+$ Potassium humate $(1 \mathrm{~g})$ 
Soil $\mathrm{pH}$ changes temporarily which ultimately reaches at its initial reading due to high soil buffering capacity. It was observed from the Table 10 that phosphoric acid decreases the salt accumulation in the soil that helps in the reclamation of salt affected soils.

\section{DISCUSSION}

Salt stress is major abiotic stress, which hinders plant growth (Abbasi et al., 2016). Some growth stages of the plant are prone to be more affected, however, it affects the whole life cycle of the plant (Qados, 2011). In case of primary salinity, it affects the plant just after germination, this effect continues up to flowering after which secondary salinity affects whole growth of the plant including flowering and fruiting stage. Potassium humate improves the growth responses including shoot and root dry weight and shoot and root length, which is might be due to more nutrient uptake. Similar results were observed by different researchers in different crops including rice (Kumar and Singh, 2017), wheat (Arancon et al., 2002). These materials can have a straightforward influence with absorption of humic containing compounds and thus influencing the enzymatic events and membrane permeability (Nardi et al., 2002). Salinity reduces plant height (Pan et al., 2019). The humic acid alone application or in combination with some other fertilizers has noteworthy valuable effect on the yield and growth of mustard (El-Abdeen and Farroh, 2019).

In present study shoot dry weight was severely affected due to the salt accumulation in shoot, however combined application of phosphoric acid and potassium humate enhanced the growth responses of the plant. The response of HA on plant growth have been described in cowpea (ElHefny, 2010) and potato (Rizk et al., 2013). There was significant positive correlation between shoot dry weight and grain yield $\mathrm{r}^{2}=0.6618$ (Fig. 1).

Potassium humate improved the potassium uptake and its translocation in other parts of the plant. Being inorganic osmo-regulator, potassium excludes the sodium and reduces its effects on the plant growth responses (Amer and ElRamady, 2015). Phosphoric acid contains phosphorus more in soluble form as compared to other solid fertilizer, when roots uptake this available phosphorus then root of the plant grows better that improves the uptake of other nutrients including macro as well as micronutrients and ultimately the shoot biomass increases (Hussain et al., 2011). PA by itself produced noteworthy increase in plant diameter and height (Rengrudkij and Partida, 2003). They also stated that adding $\mathrm{PA}$ stimulate growth response, plant dry weight $\mathrm{N}$ and $\mathrm{P}$ uptake. Figure 3 showed a significant positive relationship between phosphorus and iron concentration in grain $\left(\mathrm{r}^{2}=\right.$ 0.7454); however, both the variables are non-significantly correlated with zinc concentration in grain, although zinc concentration was increased significantly as compared to control. This is might be due to the dissolution and inter conversion of iron, phosphorus and zinc compounds. Salt affected soil has higher $\mathrm{pH}$, that decreases temporary when phosphoric acid is applied alone, which ultimately increases the phosphorus concentration in the soil. At lower $\mathrm{pH}$ value iron concentration in soil solution become more however, zinc concentration decreases due to the formation of zinc phosphate which is unavailable form. At low $\mathrm{pH} F e$ (III) reduces to $\mathrm{Fe}$ (II), which is more available form to plants. In addition, the maize plants can take up Fe (III) which should be converted into $\mathrm{Fe}$ (II) inside the plant for its better utilization. At high $\mathrm{pH}$, under salt affected conditions there are more carbonate, bicarbonate, which fix the iron and make it unavailable to the plants. Among these metals, $\mathrm{Zn}$ contests with Fe for the transporters HvIRT1, ZmYS1 (Murata et al., 2006) and HvIRT2 (Pedas et al., 2008).

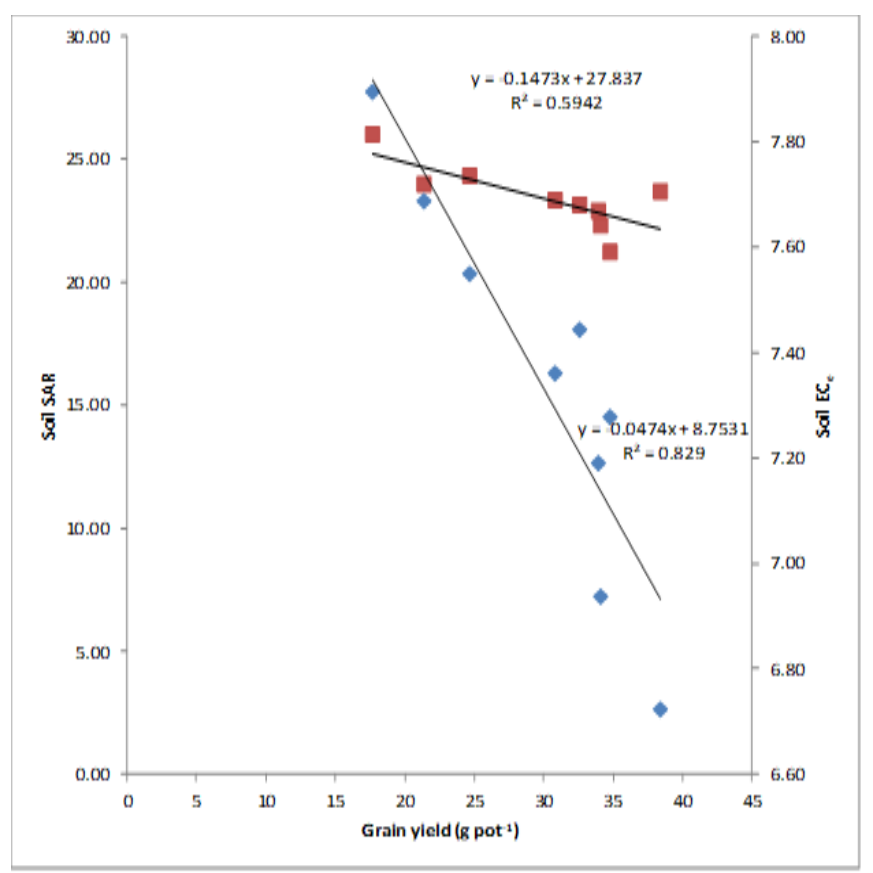

Figure 3. Correlation between grain yield, soil ECe and SAR.

Fe deficiency in graminaceous crops results the $\mathrm{Zn}$ uptake. Fe deficiency results a four-fold uptake in the $\mathrm{Zn}$ in the barley xylem sap (Alam et al., 2001). Some plants are well-known to discharge mugineic acids (MAs), which is phytosiderophores. MA solubilize mineral Fe by the process of chelation and $\mathrm{Fe}-\mathrm{MA}$ complex is absorbed at the root (Mori, 1999).

The sodium concentration increases under salt affected conditions while in salt tolerated genotype potassium uptake increases as compared to sodium concentration due to similar atomic size. The result obtained is similar with previous outcomes which describe that genotypes being highly tolerant 
to salt stress are generally able to regulate ion uptake to decrease higher accumulation of sodium in the leaves (Schmutz and Ludders., 1998; Flower et al., 1977).

Soil post-harvest analysis was very impressive which describe the significant negative correlation with grain yield. Grain yield was negatively correlated with soil SAR $\left(r^{2}=0.5942\right)$ however highly significant negative correlation was recorded between soil $\mathrm{EC}_{\mathrm{e}}$ and grain yield $\left(\mathrm{r}^{2}=0.829\right)$ at $5 \%$ level respectively (Fig. 3). The results of present experiment explain that this is might be due to the dissolution of salts. Phosphoric acid dissolved the salts more, especially the exchangeable sodium which leach down on irrigation with good quality of water. The correlation showed that as yield was increased then soil $\mathrm{EC}_{\mathrm{e}}$ and SAR decreased.

Application of $\mathrm{PH}$ either alone or in combination with other fertilizers improved the ionic concentration in plant. Combined application of phosphoric acid and potassium humate increased the grain yield. This is might be due to the increase quantity of available phosphorus and other nutrients. Similar results were reported by Akhtar et al. (2016) and Hussain et al. (2011). Phosphoric acid alone application facilitates the leaching of salts which ultimately decrease the soil EC and SAR. So, phosphoric acid could be used as a fertilizer as well as good reclaiming agent in salt affected soils. The results were in accordance of Ali and Aslam (2005).

Conclusions: Application of liquid fertilizer increases the availability of phosphorus and yield of crop. Acidic fertilizer increases the availability of macro and micronutrient due to temporary change in $\mathrm{pH}$, dissolution of fixed nutrient compounds which increase the concentration of respective nutrient in soil solution. It was concluded from the present experiment that phosphorus concentration increased significantly with phosphoric acid application; however, it does not depend on the concentration of phosphorus in phosphoric acid. Growth and yield become maximum with combined application of phosphoric acid with potassium humate in saline-sodic soil. Phosphoric acid increased the micronutrient availability when applied alone or in combination with potassium humate.

\section{REFERENCES}

Abbasi, H., M. Jamil, A. Haq, S. Ali, R. Ahmad, Z. Malik and Parveen. 2016. Salt stress manifestation on plants, mechanism of salt tolerance and potassium role in alleviating it: a review. Zemdirbyste 103:229-238.

Akhtar, M., M. Yaqub, A. Naeem, M. Ashraf and V.E. Hernandez. 2016. Improving phosphorus uptake and wheat productivity by phosphoric acid application in alkaline calcareous soils. J. Sci. Food Agric. 96:37013707.
Alam, S., S. Kamei and S. Kawai. 2001. Effect of iron deficiency on the chemical composition of the xylem sap of barley. J. Soil Sci. Plant Nutr. 47:643-649.

Ali, Y. and Z. Aslam. 2005. Use of environmental friendly fertilizers in saline and saline-sodic soils. Int. J. Environ. Sci. Technol. 1:97-98.

Amer, M. M. and H. R. El-Ramady. 2015. Alleviation soil salinity and sodicity hazard using some bio-chemical amendments for production of canola (Brassica napus) in north delta region. J. Soil Sci. Agric. Eng. 6:427-444.

Arancon, N.Q., S. Lee, C.A. Edwards and R. Atiyeh. 2002. Effects of humic acids derived from cattle, food and paper-waste vermicomposts on growth of greenhouse plants. Pedobiolog. 47:741-744.

Bouyoucos, G.J. 1962. Hydrometer method improved for making particle soil analysis of soil. J. Agron. 54:464465.

Chapman, H.D. and F. Parker. 1961. Determination of NPK: Method of analysis for soil, plant and water. Division of Agriculture, University of California, USA; pp.150-79.

El-Abdeen, H.A.Z. and K.Y. Farroh. 2019. Preparation and characterization of nano organic soil conditioners and its effected on sandy soil properties and wheat productivity. Nat. Sci. 17:115-128.

El-Hefny, E.M. 2010. Effect of saline irrigation water and humic acid application on growth and productivity of two cultivars of cowpea (Vigna unguiculata L. Walp.). Aust. J. Basic Appl. Sci. 4:6154-6168.

Flower, T.J., P.F. Troke and A.R. Yeo. 1977. The mechanism of salt tolerance in halophytes. Ann. Rev. Plant Physiol. 28:89-121.

Fong, S.S., L. Seng and H.B. Mat. 2007. Reuse of nitric acid in the oxidative pretreatment step for preparation of humic acids from low rank coal of Mukah, Sarawak. J. Braz. Chem. Soc. 18:41-46.

Hopkins, B.G. and J.W. Ellsworth. 2005. Western nutrient management. Salt Lake City, UT, USA; pp.88-94.

Hussain, F., M. Akhtar, M.Y Ashraf, T.M. Qureshi, Anwarul-Haq and A. Naeem. 2011. Evaluation of phosphoric acid as a phosphate fertilizer for wheat production on salt-affected soils. Agrochimica 5:203-211.

Kumar, D. and A.P. Singh. 2017. Efficacy of potassium humate and chemical fertilizers on yield and nutrient availability patterns in soil at different growth stages of rice. Commun. Soil Sci. Plant Anal. 48:245-261.

Liang, Y.C., W. Sun, Y.G. Zhu and P. Christie. 2007. Mechanisms of silicon mediated alleviation of abiotic stress in higher plants: a review. Environ. Pollut. 147:422-428.

Mahmood, I.A., A. Ali, M. Aslam, A. Shahzad, T. Sultan and F. Hussain. 2013. Phosphorus availability in different salt-affected soils as influenced by crop residue incorporation. Int. J. Agric. Biol. 15:472-478. 
Mohsen, S., R. Majid and G.K. Borzoo. 2009. Prediction of soil exchangeable sodium percentage based on soil sodium adsorption ratio. American Eurasian J. Agric. Environ. Sci. 5:01-04.

Mori, S. 1999. Iron acquisition by plants. Curr. Opin. Plant Biol. 2:250-253.

Murata, Y., J.F. Ma, N. Yamaji, D. Ueno, K. Nomoto and T. Iwashita. 2006. A specific transporter for iron (III)phytosiderophore in barley roots. Plant J. 46:563-572.

Nadeem, M.K., S.J. Rasool, M. Ikram, A. Jahanzab, M.F. Maqbool, H. Ahmad and R. Habib. 2018. Management of wheat production in saline soils through multi-strain bacterial inoculation. J. Glob. Innov. Agric. Soc. Sci. 6:135-142.

Nardi, S., D. Pizzeghello, A. Muscolo and A. Vianello. 2002. Physiological effects of humic substances on higher plants. Soil Biol. Biochem. 34:1527-1536.

Olsen, S.R., C.V. Cole, F.S. Watanabe and L.A. Dean. 1954. Estimation of available phosphorus in soils by extraction with sodium bicarbonate. USDA Circ. 939. Washington DC, USA.

Pan, J., F. Peng, X. Xue, Q. You, W. Zhang, T. Wang and C. Huang. 2019. The growth promotion of two salt tolerant plant groups with PGPR inoculation: A Meta-Analysis. Sustainability 11:378-392.

Pedas, P., C.K. Ytting, A.T. Fuglsang, T.P. Jahn, J.K. Schjoerring and S. Husted. 2008. Manganese efficiency in barley: identification and characterization of the metal ion transporter HvIRT1. Plant Physiol. 148:455-466.

Qados, A.M.A. 2011. Effect of salt stress on plant growth and metabolism of bean plant Vicia faba (L). J. Saudi Soc. Agric. Sci. 10:7-15.

Quader, A.K.M.A. 2009. strategy for developing the fertilizer sector in Bangladesh for sustainable agriculture. Chem. Eng. Res. Bull. 13:39-46.

Rahneshan, Z., F. Nasibi and A.A. Moghadam. 2018. Effects of salinity stress on some growth, physiological, biochemical parameters and nutrients in two pistachio (Pistacia vera L.) rootstocks. J. Plant Interact. 13:73-82.

Rehm, G., M. Schmitt, J. Lamb, G. Randall and I. Busman. 1998. Phosphorus in the agricultural environment. University of Minnesota, USA. University of Minnesota extension service, 405 Coffey Hall, St. Paul, Mn, Philippines; pp.55108-6068.

Rengrudkij, P. and G.J. Partida. 2003. The effects of humic acid and phosphoric acid on grafted Hass avocado on Mexican seedling rootstocks. Proc. World Avocado Congress; pp.395-400.
Rizk, F.A., A.M. Shaheen, S.M. Singer and O.A. Sawan. 2013. The Productivity of potato plants affected by urea fertilizer as foliar spraying and humic acid added with irrigation water. Middle East J. Agric. Res. 2:76-83.

Sarwar, G., H. Schmeisky, N. Hussain, S. Muhammad, M. Ibrahim and E. Safdar. 2008. Improvement of soil physical and chemical properties with compost application in rice-wheat cropping system. Pak. J. Bot. 40:275-282.

Schmutz, U. and P. Ludders. 1998. Effect of $\mathrm{NaCl}$ salinity and different root zone temperatures on growth and mineral composition of two mango rootstocks (Mangifera indica L). J. Appl. Bot. 72:131-135.

Sharif, M., R.A. Khattak and M.S. Sarir. 2002. Effect of different levels of lignitic coal derived humic acid on growth of maize plants. Commun. Soil Sci. Plant Anal. 33:3567-3580.

Shrivastava, P. and R. Kumar. 2015. Soil salinity: A serious environmental issue and plant growth promoting bacteria as one of the tools for its alleviation. Saudi J. Biol. Sci. 22:123-131.

Sial, M.A., M.A. Arain, S.D. Khanzada, M.H. Naqvi, N.U. Dahot and N.A. Nizami. 2005. Yield and quality parameters of wheat genotypes as affected by sowing dates and high temperature stress. Pak. J. Bot. 37:575584.

Soltanpour, P.N. and S. Workman. 1979. Modification of the $\mathrm{NaHCO}_{3}$ DTPA soil test to omit carbon black. Commun. Soil Sci. Plant Anal. 10:1411-1420.

Stark, J.C. and D.T. Westermann. 2003. Nutrient management. In: J.C. stark and S.l. Love (eds.), Potato Production Systems. University of Idaho Agricultural Communications, Moscow, USSR; pp.115-135.

Stevenson, F.J. and M.A. Cole. 1999. Cycles of soil: Carbon, nitrogen, phosphorus, sulfur and microelements, $2^{\text {nd }} \mathrm{Ed}$. John Wiley and Sons, New York, USA.

Sundhari, T., T. Thilagavathi, M. Baskar, T. Thuvasan and N. Eazhilkrishna. 2018. Effect of gypsum incubated organics used as an amendment for sodic soil in green gram. Int. J. Chem. Stud. 6:304-308.

Yoshida, S., D.A. Farno, J.H. Cock and K.A. Gomez. 1976. Laboratory manuals of physiological studies of rice. IRRI, Loss Bonas, Philippines.

Zingore, S., H.K. Murwira, R.J. Delve and K.E. Giller. 2007. Influence of nutrient management strategies on variability of soil fertility, crop yields and nutrient balances on smallholder farms in Zimbabwe. Agric. Ecosyst. Environ. 119:112-126. 